\title{
Sigara Bağımlılarında Depresyon, Anksiyete, Uykululuk ve Uyku Kalitesi Düzeyleri Arasındaki İlişkinin Belirlenmesi
}

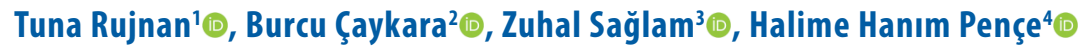

'Istanbul Medeniyet Üniversitesi, Sağlık Bilimleri Fakültesi, Sağlık Yönetimi, İstanbul, Türkiye 2istanbul Medeniyet Üniversitesi, Tıp Fakültesi, Fizyoloji, İstanbul, Türkiye ${ }^{3}$ Istanbul Medeniyet Üniversitesi, Tıp Fakültesi, Dahili Tıp, İstanbul, Türkiye ${ }^{4}$ Sağlık Bilimleri Üniversitesi, Tıp Fakültesi, Tıbbi Biyokimya, İstanbul, Türkiye

Tuna Rujnan, Dr. Öğr. Üyesi

Burcu Çaykara, Araş. Gör.

Zuhal Sağlam, Doç. Dr.

Halime Hahım Pençe, Dr. Öğr. Üyesi

Iletişim:

Dr. Öğr. Üyesi Tuna Rujnan

İstanbul Medeniyet Üniversitesi, Sağlkk Bilimleri

Fakültesi, Sağlık Yönetimi, İstanbul, Türkiye

Tel: +90 2162803153

E-Posta: rujnantuna@yahoo.com
ÖZET

Amaç: Çalışma sigara bağımlılarında anksiyete, depresyon, uykululuk ve uyku kalitesi düzeylerinin belirlenmesi, anlamlı fark oluşturan sosyodemografik özelliklerin tanımlanması ve sigara bağımlıı̆ı̆ıla anksiyete, depresyon, uykululuk ve uyku kalitesi arasındaki ilişkinin ortaya konması amacıyla gerçekleştirilmiştir.

Yöntem: Araştırma 01.05.2017-01.11.2017 tarihleri arasında İstanbul'da bir devlet hastanesinde, sigara bırakma birimine başvuran 109 bağımlıyla gerçekleştirilmiştir. Çalışma verileri Bilgi Formu, Fageström Nikotin Bağımlılık Testi, Beck Depresyon Envanteri, Beck Anksiyete Ölçeği, Hamilton Anksiyete Ölçeği, Epworth Uykululuk ölçeği ve Pittsburgh Uyku Kalitesi Indeksi kullanılarak toplanmıştır. Veriler IBM SPSS Statistics 22,0 paket programı ile analiz edilmiştir. Verilerin analizinde betimleyici ve nonparametrik testler ve korelasyon analizleri kullanılmıştır.

Bulgular: Örneklemin $\% 78,9^{\prime}$ unu erkek ve \%21,1'ini kadınlar oluşturmaktadır. Çalışma kapsamına alınan örneklemin yaş ortalaması $37,10 \pm 11,32$, günlük tükettiği ortalama sigara sayısı $22,74 \pm 11,81$ ve sigara içme süresi $19,84 \pm 11,59$ yıl olarak bulunmuştur. Sigara bağımlılarının minör ve hafif anksiyete düzeyinde, hafif depresyon düzeyinde, orta bağımlılık düzeyinde, normal uykululuk düzeyinde ve uyku kalitelerinin kötü düzeyde olduğu belirlenmiştir. Ayrıca yaş ve cinsiyetin sigara kullanımına etkisi incelendiğinde istatistiksel olarak anlamlı bir ilişki saptanmıştır $(p<0,05)$. Sigara bağımlılarııın anksiyete, depresyon, bağımlılık, uykululuk ve uyku kalitesi düzeylerinin aralarında anlamlı ilişki olduğu $(p<0,01)$ saptanmıştır.

Sonuç: Sigara bağımılıarının anksiyete, depresyon düzeylerinin azaltılması; uykululuk sorununun çözümü ve uyku kalitelerini artırmaya yönelik eğitimlerinin düzenlenmesi önerilebilir.

Anahtar sözcükler: Anksiyete, depresyon, uyku bozukluğu, sigara içme

THE DETERMINATION OF THE RELATIONSHIP BETWEEN LEVELS OF DEPRESSION, ANXIETY, SLEEPINESS AND SLEEP QUALITY IN SMOKING ADDICTS

\section{ABSTRACT}

Objectives: The study was conducted to determine the levels of anxiety, depression, sleepiness and sleep quality in smoking addicts, to identify the socio-demographic characteristics that make a meaningful difference, and to reveal the relationship between smoking addiction and anxiety, depression, sleepiness and sleep quality.

Methods: The study was conducted with 109 addicts who applied to a smoking cessation unit in a state hospital in Istanbul between 01.05.2017-01.11.2017. Data were collected via the Data Form, Fagerström Test for Nicotine Dependence Test, Beck Depression Inventory, Beck Anxiety Inventory, Hamilton Anxiety Scale, Epworth Sleepiness Scale, and Pittsburgh Sleep Quality Index. The data were analyzed with the IBM SPSS Statistics 22.0 package program. Descriptive and nonparametric tests and correlation analyzes were used in the analysis of the data.

Results: The sample consisted of $78.9 \%$ male and $21.1 \%$ female. The mean age of the sample was $37.10 \pm 11.32$, the average number of cigarettes consumed per day was $22.74 \pm 11.81$ and the duration of smoking was $19.84 \pm 11.59$ years. It has been determined that smoking addicts have minor and mild anxiety, mild depression, moderate addiction, normal sleepiness and poor sleep quality. Also, age and gender were statistically significant to the smoking effect $(p<0.05)$. There was a significant correlation between the levels of smoking, depression, addiction, sleepiness, and sleep quality of cigarette addicts $(p<0.01)$.

Conclusion: The reduction of anxiety and depression levels of smoking addicts is clear in the study results; it may be advisable to organize training for sleepiness problems and for improving sleep quality.

Keywords: Anxiety, depression, sleep disorder, smoking
Gönderilme Tarihi : 23 Mart 2018

Revizyon Tarihi : 29 Nisan 2018

Kabul Tarihi : : 13 Mayıs 2018 
igara içme alışkanlığı günümüzün en önemli sağlık sorunlarından biri olarak ifade edilmektedir. Insanlar ciddi hastalıklara yakalanacaklarını bilmelerine karşın bu alışkanlıklarını bırakmayı düşünmemekte ya da bırakamamaktadırlar. Çoğu insan sigarayı bırakması durumunda kendisini boşlukta hissedeceğini, dikkatinin dağılacağını, iş veriminin düşeceğini, duygu ve düşüncelerini ifade etmekte zorluk çekeceğini ve kimi defa da sigarasız yaşayamayacaklarını ifade etmektedir (1).

İnsan sağlığı üzerinde olumsuz etkileri olan sigara kullanımının, ruhsal rahatsızlıklarla da yakından ilişkili olduğu ifade edilmektedir (2). Ruh sağlığına bağlı rahatsızlıklarda depresyonun özellikle de anksiyetenin sigara kullanımını bırakmaya çalışan bağımlılarda başarısızlığa neden olduğu ve bağımlıı̆ın tekrarlanmasına neden olduğu da belirtilmektedir $(2,3)$.

Yapılan çalışmalarda tek başına depresyona oranla anksiyete ve kronik depresyonun bir arada görülmesinin sigara bağımlılığıyla daha yakından ilişkili olduğu belirtilmektedir $(2,3)$. Bu bulguyu destekler nitelikte anksiyetenin de sigara içmeyenlere oranla sigara içenlerde daha yüksek düzeyde olduğu belirlenmiştir (3). McClave ve arkadaşları (4)'nın çalışmasında da depresyon oranı sigara bırakma eğilimi olanlarda \%27,3, sigara bırakma eğilimi olmayanlarda $\% 33$, başaranlarda ise $\% 20,3$ olarak bulunmuştur.

Sigara bağımlılığıyla yakından ilişkili olan kavramlardan bir diğeri de uyku bozukluklarıdır. Uyku bozukluklarının yaş, cinsiyet, sosyoekonomik durum, tıbbi ve psikiyatrik rahatsızlıklar, alkol ve sigara bağımlılığı, yaşam stresi, ilaç kullanımıyla doğrudan ilişkili olduğu ifade edilmiştir (5). Sigara alışkanlığı ile uyku bozuklukları ve kalitesine yönelik Mak ve arkadaşları tarafından yapılan çalışmada; sigara içenlerin uykuya dalmakta zorluk yaşama, uyuya kalma, erkenden uyanma ve tüm gün uykulu olma gibi uyku problemleri yaşadıkları belirlenmiştir (6). Bununla birlikte uyku ile ilgili bozukluklar; yaşamı tehdit eden kazalara, iş ve mesleki verimlilikte kayıplara, ciddi psikolojik problemlere, bilişsel yeti kayıplarına neden olan; bireyin yaşam kalitesini doğrudan etkileyen önemli bir sağlık problemi olarak ifade edilmektedir (7). Bununla birlikte yapılan bazı çalışmalarda sigara bağımlıı̆ı̆ıla uyku kalitesi ve uykululuk durumu ile cinsiyet değişkeni arasında anlamlı fark bulunurken $(p<0,05)(8,9)$; bazı çalışmalarda ise uyku kalitesinin yaş ve cinsiyete göre farklılık göstermediği $(p>0,05)$ saptanmıştır $(10,11)$.
Tüm bu yönleriyle insan sağlığını doğrudan tehdit eden başta fiziksel, ruhsal, sosyal, ekonomik olmak üzere yaşam kalitesini olumsuz etkileyen sigara bağımlıığının anlaşıması önem taşımaktadır.

\section{Gereç yöntem}

Araştırmanın amacı ve türü

Bu çalışma sigara bağımlılarında anksiyete, depresyon, uykululuk ve uyku kalitesi düzeylerinin belirlenmesi, anlamlı fark oluşturan sosyodemografik özelliklerin tanımlanması ve sigara bağımlılığıyla anksiyete, depresyon, uykululuk ve uyku kalitesi arasındaki ilişkinin ortaya konması amacıyla tanımlayıcı, kesitsel ve ilişki belirleyici tasarımda gerçekleştirilmiştir.

\section{Araştırma soruları}

Araştırmada yanıtlanması beklenen sorular:

- Sigara bağımlılarının anksiyete, depresyon, uykululuk ve uyku kalitesi düzeyleri nasıldır?

- Sigara bağımlıı̆̆ı üzerinde anlamlı fark oluşturan demografik özellikler hangileridir?

- Sigara bağımlıı̆ıyla anksiyete, depresyon, uykululuk ve uyku kalitesi arasındaki anlamlı bir ilişki var mıdır?

\section{Araştırmanın evreni ve örneklemi}

Araştırma evrenini, İstanbul ilinde bir devlet hastanesinin sigara bırakma birimine başvuran bireylerden, herhangi bir örneklem seçim yöntemine gidilmeksizin evren kapsamındaki ve çalışmaya katılmayı kabul eden tüm sigara bağımlıları, 109 kişi örneklem kapsamına alınmıştır.

\section{Verilerin toplanması ve veri toplama araçları}

Araştırma verileri 01.05.2017-01.11.2017 tarihleri arasında örneklem kapsamında yer alan hastanenin yöneticileri ile ön görüşmeler yapılarak, çalışmaya katılmayı kabul eden sigara bağımlıları ile gerçekleştirilmiştir. Araştırmaya katılmaya kabul eden bireylere, çalışma hakkında gerekli açıklamalar yapılmışolurları alındıktan sonra, veri toplama aracı elden dağıtılarak ve aynı gün içerisinde geri toplanmıştır.

Araştırmada sigara bağımlılarının kişisel ve bağımlılığa ilişkin özelliklerini değerlendirmek için araştırmacılar tarafından oluşturulan 18 soruluk "Bilgi Formu”, "Fageström Nikotin Bağımlılık Testi","Beck Depresyon Envanteri", "Beck Anksiyete Ölçeği”, "Hamilton Anksiyete Ölçeği", "Epworth Uykululuk Ölçeği" ve "Pittsburgh Uyku Kalitesi İndeksi" kullanılmıştır. 
Fagerstrom Nikotin Bağımlılık Testi (FNBT): Fagerstrom Nikotin Bağımlılık Testi, Karl O. Fagerstrom tarafından sigaraya olan fiziksel bağımlılığın düzeyini saptamak amacıyla geliştirilmiş olup altı sorudan oluşmaktadır (12). Sorular kapalı uçludur. Sigaraya bağımlııık düzeyi arttıkça testten alınan puan artmaktadır. Testten 5 puanın altında alanlar hafif, 5 veya 6 puan alanlar orta, 7 puan ve üstünde alanlar şiddetli nikotin bağımlısı olarak tanımlanmaktadır. Testin Türk dilinde geçerlilik ve güvenirlik çalışması Uysal ve arkadaşları tarafından yapılmış ve Cronbach's alfa değeri 0,56 olarak bulunmuştur ( $a<0,40$ güvenilir değil; $0,40 \leq a \leq 0,50$ çok düşük güvenirlik düzeyi; $0,50 \leq a \leq 0,60$ düşük güvenirlik düzeyi; $0,60 \leq a \leq 0,70$ yeterli güvenirlik düzeyi; $0,70 \leq a \leq 0,90$ yüksek güvenirlik düzeyi; $a \geq 0,90$ çok yüksek güvenirlik düzeyi) (13).

Beck Depresyon Envanteri (BDE): Envanter Beck ve arkadaşları tarafından geliştirilmiştir, her yanıttan elde edilen 0-3 arasındaki puanların toplanması ile değerlendirilen, toplam 21 sorudan oluşan bir depresyon derecelendirme ölçeğidir (14). Denk düşen puan aralıkları doğrultusunda ölçek, 0-9 arası minimal, 10-16 arası hafif derecede duygu durumu bozukluğu, 17-29 arası orta depresyon; 30-63 arası şiddetli depresyon biçiminde değerlendirilmektedir. Ölçeğin Türkçe geçerlilik ve güvenilirlik çalışması Hisli tarafından yapılmış olup, iç tutarlııı katsayısı 0,74 olarak bulunmuştur (15).

Beck Anksiyete Ölçeği (BAÖ): Ölçek, Beck ve arkadaşları tarafından geliştirilen ve bireylerin yaşadığı anksiyete belirtilerinin sıklığının belirlenmesi amacıyla kullanılan kendini değerlendirme ölçeğidir (16). 21 maddeden oluşan, 0-3 arası puanlanan likert tipi bir ölçektir. Türkiye'de geçerlik ve güvenirliği Ulusoy ve arkadaşları tarafından yapılmış ve iç tutarlılık katsayısı 0,93 olarak belirlenmiştir (17).

Hamilton Anksiyete Ö/çeği (HAÖ): Ölçek, Hamilton tarafından geliştirilmiştir (18). Ölçek deneklerde anksiyete düzeyini ve belirti dağııımını belirlemek ve şiddet değişimini ölçmek için kullanılmaktadır. Ölçeğin Türkçe geçerlilik ve güvenilirliği Yazıcı ve arkadaşları tarafından yapılmış ve iç tutarlııık katsayısı 0,94 olarak belirlenmiştir (19).

Epworth Uykululuk Ölçeği (EUÖ): EUÖ Johns tarafından geliştirilmiştir (20). EUÖ dörtlü likert tipi bir ölçektir. 0, 1, 2, 3 şeklinde puanlanmakta ve yüksek puan uykululuğu göstermektedir. Ölçeğin değerlendirilmesinde 0-5 puan aralığı normal, 6-10 puan aralığı normal ama artmış gün içi uykululuk, 11-12 puan aralığı artmış ama ılımlı gün içi uykululuk, 13-15 puan aralığı artmış, orta derecede gün içi uykululuk ve 16-24 puan aralığı da artmış, şiddetli gün içi uykululuk olarak değerlendirilmektedir. EUÖ'nün genel uykululuk düzeyini değerlendirmede geçerli ve güvenilir bir ölçek olduğu ve Türkiye'de uyku ve uyku bozukluklarıyla ilgili çalışmalarda kullanılabilecek geçerli ve güvenilir bir test olduğu (Cronbach's alfa $=0,86$ ) belirtilmiştir (21).

Pittsburgh Uyku Kalitesi Indeksi (PUKi): PUKI, Buysse ve arkadaşları (22) tarafından geliştirilmiş (Cronbach's alfa=0,80), Türkçe geçerlilik ve güvenilirlik çalışması Ağargün ve arkadaşları tarafından yapılmış olup iç tutarlıık katsayısı 0,80 olarak bildirilmiştir (23). PUKi, bir aylık bir zaman aralığındaki uyku kalitesi ve bozukluğunu değerlendiren bir öz bildirim ölçeğidir. Her birinin yanıtı belirti sıklığına göre 0-3 arasında puanlanır. Toplam puan 0-21 arasında bir değere sahiptir. Yüksek değerler uyku kalitesinin kötü, uyku bozukluğu seviyesinin yüksek olduğunu gösterir. Toplam puanın 5 'in üzerinde olması klinik olarak uyku kalitesinin kötü olduğunu gösterir (23).

\section{Verilerin değerlendirilmesi}

Veriler IBM SPSS Statistics 22,0 paket programı ile analiz edilmiştir. Verilerin analizinde betimleyici (sayı, yüzde, ortalama ve standart sapma) ve nonparametrik testler ve korelasyon analizleri kullanılmıştır.

\section{Araştırmanın etik yönü}

Çalışmaya başlanmadan önce çalışma verilerinin toplanacağı ölçüm araçlarının kullanım izinleri alınmıştır. Araştırma verilerinin toplanmasına etik kurul (Karar no: 2017/0118, Tarih: 18.04.2017), çalışmanın yapılmasının planlandığı hastaneden kurum izni ve araştırmaya katılan gönüllülerden bilgilendirilmiş onam alındıktan sonra başlanmıştır.

\section{Bulgular}

Çalışma kapsamına alınan örneklemin \%78,9 (86 kişi)'unu erkekler, \%21,1 (23 kişi)'ini kadınlar oluşturmakta olup;

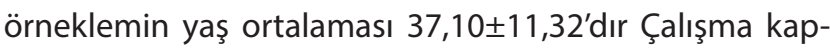
samına alınan örneklemin günlük tükettiği ortalama sigara sayısı ortalama $22,74 \pm 11,81$ ve sigara içme süresi $19,84 \pm 11,59$ yıl olarak bulunmuştur.

\section{Bireylerin ölçeklerden elde ettiği ortalama puanlar}

Çalışma kapsamına alınan örneklemin ölçeklerden aldıkları ortalama puanları değerlendirildiğinde; HAÖ'den aldıkları ortalama puan $11,28 \pm 10,55$ ve minör anksiyete düzeyinde, BDÖ'den aldıkları ortalama puan $11,35 \pm 9,62$ ve hafif düzeyde, BAÖ'den aldıkları ortalama puan $8,77 \pm 8,77$ ve hafif düzeyde, $F N B T^{\prime}$ den aldıkları ortalama puan $4,63 \pm 2,41$ ve orta düzeyde, EUÖ'den aldıkları ortalama 
puan $5,39 \pm 4,17$ ve normal uykululuk düzeyinde, PUKi'den aldıkları ortalama puan ise $5,83 \pm 2,95$ ve uyku kalitesi kötü düzeyde belirlenmiştir (Tablo 1).

\section{Sosyodemografik özelliklere göre ölçek puanlarının} karşılaştırılması

Sigara bağımlılarının HAÖ, BDE, BAÖ, FNBT, EUÖ ve PUKi'den aldıkları ortalama puanlarlar cinsiyete göre karşılaştırıldığında; her iki ölçekten de alınan puanlara göre

Tablo 1. Sigara bağımlıarının anksiyete, depresyon, nikotin bağımllık, uykululuk ve uyku kalitesi düzeyleri puan ortalamaları

\begin{tabular}{lccccc} 
& $\alpha$ & $\overline{\boldsymbol{x}}$ & $\mathbf{\pm s \boldsymbol { d }}$ & Min & Max \\
\hline Hamilton Anksiyete & 0,74 & 11,28 & 10,55 & 0 & 48,00 \\
Beck Depresyon & 0,76 & 11,35 & 9,62 & 0 & 47,00 \\
Beck Anksiyete & 0,92 & 8,77 & 8,77 & 0 & 46,00 \\
Fagerström Nikotin Bağımlıık & 0,65 & 4,63 & 2,41 & 0 & 9,00 \\
Epworth Uykululuk & 0,84 & 5,39 & 4,17 & 0 & 19 \\
Pittsburgh Uyku Kalitesi & 0,76 & 5,83 & 2,95 & 0 & 15 \\
\hline X̄: Ortalama, \pm sd: Standart sapma, Min: Minimum, Max: Maximum
\end{tabular}

anksiyete düzeyleri arasında ve uyku kalitesine göre kadın sigara bağımlılarından kaynaklanan çok yüksek düzeyde anlamlı fark bulunduğu $(p \leq 0,001)$, depresyon düzeyleri arasında da kadın sigara bağımlılarından kaynaklanan yüksek düzeyde anlamlı fark bulunduğu $(p<0,01)$, nikotin bağımlılık düzeyleri ve uykululuk düzeyleri arasında ise cinsiyete göre anlamlı bir fark bulunmadığı $(p>0,05)$ belirlenmiştir (Tablo 2).

Sigara bağımlılarının HAÖ, BDÖ, BAÖ, FNBT, EUÖ ve PUKI'den aldıkları ortalama puanlar yaşa göre karşılaştırıldığında; depresyon, Beck anksiyete, nikotin bağımlıık, uykululuk durumu ve uyku kalitesi düzeyleri arasında anlamIı bir fark bulunmadığı $(p>0,05)$, buna karşın HAÖ'ne göre anksiyete düzeyleri arasında 35-45 yaş aralığındaki sigara bağımlılarından kaynaklanan anlamlı bir fark bulunduğu $(p<0,05)$ belirlenmiştir (Tablo 3).

\section{Ölçümler arası ilişkiler}

Sigara bağımlılarının anksiyete, depresyon, nikotin bağımlılık, uykululuk ve uyku kalitesi düzeyleri arasındaki

Tablo 2. Sigara bağımılıarının anksiyete, depresyon, nikotin bağımllık, uykululuk ve uyku kalitesi düzeyinin cinsiyete göre karşıșştırması (N: 109)

\begin{tabular}{|c|c|c|c|c|c|c|c|c|}
\hline \multirow[b]{2}{*}{ Değişkenler } & \multicolumn{3}{|c|}{ Kadın (n:23) } & \multicolumn{3}{|c|}{ Erkek (n:86) } & \multirow[b]{2}{*}{$Z M U$} & \multirow[b]{2}{*}{$p$} \\
\hline & $\bar{x}$ & $\pm s d$ & Mean Rank & $\overline{\boldsymbol{x}}$ & $\pm s d$ & Mean Rank & & \\
\hline Hamilton Anksiyete & 19,35 & 11,65 & 79,17 & 9,13 & 9,17 & 48,53 & $-4,136$ & $0,000^{* * *}$ \\
\hline Beck Depresyon & 16,65 & 10,11 & 73,57 & 9,93 & 9,03 & 50,03 & $-3,175$ & $0,002^{\star *}$ \\
\hline Beck Anksiyete & 15,39 & 9,22 & 79,85 & 7,00 & 7,80 & 48,35 & $-4,255$ & $0,000 * \star *$ \\
\hline Fagerström Nikotin Bağımlılık & 5,35 & 2,23 & 63,72 & 4,44 & 2,44 & 52,67 & $-1,500$ & 0,134 \\
\hline Epworth Uykululuk & 6,43 & 4,88 & 61,20 & 5,12 & 3,94 & 53,24 & $-1,063$ & 0,288 \\
\hline Pittsburgh Uyku Kalitesi & 7,52 & 2,27 & 73,54 & 5,37 & 2,84 & 50,04 & $-3,191$ & $0,001^{\star \star *}$ \\
\hline
\end{tabular}

Tablo 3. Sigara bağımlıarının anksiyete, depresyon, nikotin bağımlılık, uykululuk ve uyku kalitesi düzeyinin yaşa göre karşılaştırması (N: 109)

\begin{tabular}{|c|c|c|c|c|c|c|c|c|c|c|c|c|c|c|}
\hline & & $\begin{array}{r}5 \text { Yaş A } \\
\text { (n: } 20\end{array}$ & & $25-3$ & $\begin{array}{l}35 \text { Yaş } \\
\text { (n:27 }\end{array}$ & |ralığı & & $\begin{array}{r}45 \text { Yaş } \\
\text { (n: } 32)\end{array}$ & ralığı & 45 ve & $\begin{array}{l}\text { zeri Ya } \\
\text { (n: 30) }\end{array}$ & Aralığı & & \\
\hline Değişkenler & $\overline{\boldsymbol{x}}$ & $\pm s d$ & $\begin{array}{c}\text { Mean } \\
\text { Rank }\end{array}$ & $\bar{x}$ & $\pm s d$ & $\begin{array}{l}\text { Mean } \\
\text { Rank }\end{array}$ & $\overline{\boldsymbol{x}}$ & $\pm s d$ & $\begin{array}{l}\text { Mean } \\
\text { Rank }\end{array}$ & $\overline{\boldsymbol{x}}$ & $\pm s d$ & $\begin{array}{l}\text { Mean } \\
\text { Rank }\end{array}$ & $X 2 k W$ & $p$ \\
\hline Hamilton Anksiyete & 12,90 & 6,99 & 67,08 & 12,11 & 9,46 & 60,28 & 8,97 & 12,11 & 42,94 & 11,93 & 11,70 & 55,07 & 8,358 & 0,039 * \\
\hline Beck Depresyon & 12,40 & 7,21 & 63,15 & 11,22 & 9,28 & 54,67 & 11,36 & 12,25 & 50,59 & 10,73 & 8,48 & 54,57 & 1,964 & 0,580 \\
\hline Back Anksiyete & 9,40 & 8,22 & 60,15 & 8,89 & 8,14 & 56,93 & 7,50 & 9,64 & 47,80 & 9,60 & 9,02 & 57,52 & 2,495 & 0,476 \\
\hline Fagerström Nikotin Bağımlılık & 3,95 & 2,33 & 46,65 & 4,78 & 2,75 & 56,20 & 4,25 & 2,20 & 49,53 & 5,37 & 2,27 & 65,32 & 5,668 & 0,129 \\
\hline Epworth Uykululuk & 5,95 & 3,15 & 63,32 & 5,29 & 3,98 & 54,96 & 5,72 & 2,02 & 54,56 & 4,77 & 4,03 & 49,95 & 2,177 & 0.537 \\
\hline Pittsburgh Uyku Kalitesi & 5,50 & 2,04 & 53,60 & 6,11 & 3,07 & 60,15 & 5,25 & 3,16 & 45,64 & 6,40 & 3,12 & 61,28 & 4,817 & 0,186 \\
\hline
\end{tabular}


Tablo 4. Sigara bağımılırında anksiyete, depresyon, nikotin bağımlılı̆ı, uykululuk ve uyku kalitesi arasındaki ilişki

\begin{tabular}{|c|c|c|c|c|c|c|c|c|c|c|}
\hline & \multicolumn{2}{|c|}{ Hamilton Anksiyete } & \multicolumn{2}{|c|}{ Beck Depresyon } & \multicolumn{2}{|c|}{ Beck Anksiyete } & \multicolumn{2}{|c|}{ Epworth Uykululuk } & \multicolumn{2}{|c|}{ Pittsburgh Uyku Kalitesi } \\
\hline & $r$ & $p$ & $r$ & $p$ & $r$ & $p$ & $r$ & $p$ & $r$ & $p$ \\
\hline Hamilton Anksiyete & 1 & & 0,586 & $0,000^{* * *}$ & 0,747 & $0,000 * \star *$ & 0,364 & $0,000^{* * *}$ & 0,561 & $0,000^{\star \star \star}$ \\
\hline Beck Depresyon & 0,586 & $0,000 * * *$ & 1 & & 0,615 & $0,000 * \star *$ & 0,379 & $0,000 * \star *$ & 0,487 & $0,000 * * *$ \\
\hline Back Anksiyete & 0,747 & $0,000^{* * *}$ & 0,615 & $0,000^{* * *}$ & 1 & & 0,426 & $0,000 * * *$ & 0,455 & $0,000^{* \star *}$ \\
\hline Fagerström Nikotin Bağımlılık & 0,278 & $0,003^{* *}$ & 0,181 & 0,060 & 0,353 & $0,000 * \star \star$ & 0,068 & 0,482 & 0,112 & 0,245 \\
\hline Epworth Uykululuk & 0,364 & $0,000^{* * *}$ & 0,379 & $0,000 * \star \star$ & 0,426 & $0,000 * * \star$ & 1 & & 0,263 & 0,006 ** \\
\hline
\end{tabular}

ilişki incelendiğinde; Hamilton anksiyete düzeyi ile Beck depresyon ve Beck anksiyete, uykululuk ve uyku kalitesi düzeyleri arasında pozitif yönde çok yüksek düzeyde anlamlı bir ilişki olduğu $(p<0,001)$; Beck depresyon ile Beck anksiyete, uykululuk ve uyku kalitesi düzeyleri arasında da pozitif yönde ve çok yüksek düzeyde anlamlı bir ilişki olduğu ( $p<0,001)$; ayrıca Beck anksiyete düzeyi ile uykululuk ve uyku kalitesi düzeyleri arasında da pozitif yönde ve çok yüksek düzeyde anlamlı bir ilişki olduğu $(p<0,001)$ belirlenmiştir. Çalışmada ayrıca nikotin bağımlılık düzeyi ile Beck anksiyete düzeyi arasında pozitif yönde ve yüksek düzeyde anlamlı bir ilişki $(p<0,01)$ belirlenirken; Hamilton aksiyete düzeyi ile arasında ise pozitif yönde ve çok yüksek düzeyde anlamlı bir ilişki $(p<0,001)$ olduğu saptanmıştır. Yine çalışma kapsamına alınan örneklemin uykululuk durumu ile uyku kalitesi arasında pozitif yönde yüksek düzeyde anlamlı bir ilişki $(p<0,01)$ bulunmuştur (Tablo 4).

\section{Tartışma}

Günümüzde en önemli sağlık sorunlarından biri olan ve ölümcül sonuçları olan sigara bağımlıığının altında yatan nedenlerin belirlenmesi ve ortaya konulması, sigara bağımlılı̆ının önlenmesinde büyük önem taşımaktadır.

\section{Bireylerin ölçeklerden elde ettiği ortalama puanlar}

Çalışma kapsamına alınan sigara bağımlılarının HAÖ'ne göre minör düzeyde anksiyete, BDÖ'ne göre hafif düzeyde depresyon, BAÖ'ne göre hafif düzeyde anksiyete, FNBT'ne göre orta düzeyde bağımlılık, EUÖ'ne göre de normal uykululuk düzeyinde ve PUKI'ye göre ise uyku kalitesi kötü düzeyde belirlenmiştir.

Kutlu ve arkadaşları tarafından polis memurlarıyla yapılan çalışmada FNBT'ne göre bağımlılık düzeyinin $\% 64,0^{\prime} ı n d a$ ( $n=132$ ) çok az ve az bağımlılık düzeyinde yer aldığı belirlenmiştir (24). Beck Depresyon sonuçlarına göre büyük çoğunluğunun $\% 58,1$ 'sinin $(n=286)$ normal düzeyde depresyonda olduğu bulunmuştur. Beck depresyon orta-

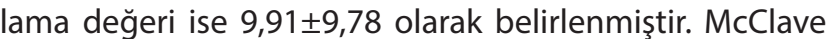
ve arkadaşları'nın sigara bağımlıları ile yaptıkları çalışmada ise örneklemin \%55,5'inin erkek, \%44,5'inin kadın olduğu; \%20,3'nün yaşam boyu depresyon, \%14,9'nun yaşam boyu anksiyete deneyimlediği ve hem depresyon hem de anksiyeteyi bir arada deneyimleyenlerin oranının ise $\% 10,1$ olduğu ifade edilmiştir (4).

Karatay ve arkadaşları tarafından hemşirelik öğrencilerinin uyku alışkanlıklarının belirlenmesi için yapılan çalışmada da PUKI puan ortalamasının 6,39 $\pm 3,82$ olduğu ve sigara içenlerden kaynaklanan $(7,96 \pm 4,11)$, istatistiksel olarak anlamlı derecede fark olduğu görülmüştür $(p<0,05)(25)$.

\section{Sosyodemografik özelliklere göre ölçek puanlarının karşılaştırılması}

Çalışmada sigara bağımlılarının aksiyete, depresyon, bağımlılık, uykululuk ve uyku kalitesi cinsiyete göre karşılaştırıldığında sadece; anksiyete düzeyleri ve uyku kalitesi arasında, kadın sigara bağımlılarından kaynaklanan çok yüksek düzeyde anlamlı fark bulunduğu $(p<0,001)$, depresyon düzeyleri arasında da kadın sigara bağımlılarından kaynaklanan yüksek düzeyde anlamlı fark bulunduğu $(p<0,01)$ belirlenmiştir. Yine çalışmada sigara bağımlılarının yaşa göre de sadece "HAÖ"den alınan toplam puana göre anksiyete düzeyleri arasında 35-45 yaş aralığındaki sigara bağımlılarından kaynaklanan anlamlı bir fark bulunduğu $(p<0,05)$ belirlenmiştir.

Kutlu ve arkadaşları tarafından polis memurlarıyla yapılan çalışmada; cinsiyet, medeni durum, eğitim düzeyi, borçlu olmak, okula giden çocuk sayısı sigara içme davranışı üzerine etkili olmadığı $(p>0,05)$; yine cinsiyet, yaş, medeni durum, eğitim düzeyinin depresyon üzerine etkili olmadığı ( $p>0,05)$ belirlenmiştir (24). Hemşirelerle yapılan bir başka çalışmada da yaş ile sigara bağımlılığı arasında anlamlı bir ilişki olmadığı bulunmuştur (26). Buna karşın çalışma 
bulgularını destekler nitelikte yapılan başka bir çalışmada depresyon ve anksiyetenin yaş ve cinsiyet ile arasında yakın bir ilişki olduğu belirlenmiştir (3).

Buysse ve arkadaşları tarafından yapılan çalışmada da cinsiyet ve EUÖ arasında anlamlı fark bulunmazken $(p>0,05)$, PUKI ile cinsiyet arasında ise anlamlı bir fark bulunmuştur $(p<0,05)(8)$. Knutson ve arkadaşları tarafından yapılan çalışmada ise hem PUKI hem de EUÖ ile cinsiyet arasında anlamlı bir fark bulunmuş $(p<0,05)$ olup çalışma sonucunu destekler niteliktedir (9). Altıntaş ve arkadaşları tarafından yapılan bir başka çalışmada da üniversite öğrencilerinin EUÖ'ye göre uykululuk durumu ile cinsiyeti ve yaşı arasında anlamlı bir fark belirlenmemiştir $(p>0,05)(27)$.

Üstün ve Çınar Yücel tarafından hemşirelerin uyku kalitesini incelemek amacıyla yapılan araştırmada; PUKi toplam puan ortalamaları 5,96 $\pm 2,90$ olarak belirlenmiş olup, \%50,5'inin uyku kalitesinin kötü olduğu bulunmuştur (28). Hemşirelerin, yaşa ve sigara içme durumlarına göre PUKi toplam puan ortalamaları arasında anlamlı bir fark olmadığı saptanmıştır $(p>0,05)$.

\section{Ölçümler arası ilişkiler}

Çalışmada sigara bağımlılarının anksiyete, depresyon, nikotin bağımlılık, uykululuk ve uyku kalitesi düzeyleri arasındaki ilişki incelendiğinde aralarında pozitif yönlü ve anlamlı bir ilişki olduğu belirlenmiştir $(p<0,01)$. Mykletun ve arkadaşları tarafından sigara bağımlılarıyla yapılan bir çalışmada aksiyete ve sigara bağımlılığı arasında depresyona göre daha güçlü bir ilişki olduğu; anksiyete ve depresyon arasında güçlü bir bağ olduğu ve bu ilişkinin kadın ve daha genç olanlarda daha da güçlü olduğu bulunmuş olup çalışma bulgularını destekler niteliktedir (3).

\section{Kaynaklar}

1. Feldner MT, Babson KA, Zvolensky MJ. Smoking, traumatic event exposure, and post traumatic stress: a critical review of the empirical literature. Clin Psychol Rev 2007;27:14-45. [CrossRef]

2. Morissette SB, Tull MT, Gulliver SB, Kamholz BW, Zimering RT. Anxiety, anxiety disorders, tobacco use, and nicotine: a critical review of interrelationships. Psychol Bull 2007;133:245-72. [CrossRef]

3. Mykletun A, Overland S, Aaro LE, Liabø HM, Stewart R. Smoking in relation to anxiety and depression: Evidence from a large population survey: The HUNT study. Eur Psychiatry 2008;23:77-84. [CrossRef]

4. McClave AK, Dube SR, Strine TW Kroenke K, Caraballo RS, Mokdad AH. Associations between smoking cessation and anxiety and depression among U. S. adults. J Addict Behav 2009;34:491-7. [CrossRef]

5. Sahlin C, Franklin KA, Stenlund $H$, Lindberg E. Sleep in women: Normal values for sleep stages and position and the effect of age, obesity, sleep apnea, smoking, alcohol and hypertension. Sleep Med 2009;10:1025-30. [CrossRef]
Asghari ve arkadaşları sigara içen ve içmeyenlerin uyku kalitelerinin karşılaştırılmasına yönelik yaptığı çalışmada da uyku kaliteleri arasında yüksek düzeyde anlamlı bir fark olduğu $(p \leq 0,01)$ saptanmıştır (29). Buysse ve arkadaşları (8) ise PUKI ve EUÖ arasındaki ilişkiyi belirlemek için yapılan çalışmada uyku kalitesi $(6,3 \pm 3,4)$ ve uykululuk durumu $(8,2 \pm 3,9)$ arasında zayıf $(r=0,16, p=0,03)$ bir ilişki belirlerken; uyku kalitesi (PUKi) ve uykululuk (EUÖ) durumunun değerlendirildiği bir başka çalışmada anksiyete, stres ve yorgunluğun uyku kalitesi ve uykululuk durumuyla ilişkili olduğu bulunmuştur (30).

Saygılı ve arkadaşları'nın üniversite öğrencileriyle yaptığı çalışmada uyku kalitesi sigara içme durumuna göre farklılık göstermektedir $(p<0,05)(10)$. Çalışmada, sigara içenlerin uyku kalitesi en kötü iken hiç sigara içmeyenlerin en iyi düzeydedir. Yine Şenol ve arkadaşları tarafından sigara kullanan adolesanların uyku kalitesini belirlemeye yönelik yapılan bir başka çalışmada da \%54,7'sinin kötü uyku kalitesine sahip olduğu da ifade edilmiştir (11).

\section{Sonuç ve öneriler}

Çalışma sonucunda sigara bağımlılığıyla anksiyete, depresyon, uykululuk ve uyku kalitesi arasındaki arasında anlamlı bir ilişki olduğu ve yaş ile cinsiyet değişkenlerine göre anlamlı fark gösterdikleri belirlenmiştir. Çalışma sonuçları bir bütün olarak değerlendirildiğinde; sigara bağımlıığını artırıcı anksiyete ve depresyon düzeylerini azaltmaya yönelik rehabilitasyon ve sosyal destek hizmetlerinin sunulması önerilebilir. Ayrıca, uyku kalitesini olumsuz etkileyen ve bireylerin günlük hayatını doğrudan olumsuz etkileyen uykululuk durumları ile sigara bağımlılığı arasındaki ilişki konusunda bireylerin bilinçlendirilmesi önem taşımaktadır.
6. Mak KK, Ho SY, Thomas GN, Lo WS, Cheuk DKL, Lai YK, Lam TH. Smoking and sleep disorders in Chinese adolescents. Sleep Med 2010;11:268-73. [CrossRef]

7. Williams $K E$, Reeves $K R$, Billing $C B$, Pennington $A M$, Gong J. $A$ double-blind study evaluating the long-term safety of varenicline for smoking cessation. Curr Med Res Opin 2007;23:793-801. [CrossRef]

8. Buysse DJ, Hall ML, Strollo PJ, Kamarck TW, Owens J, Lee L, et al. Relationships between the Pittsburgh Sleep Quality Index (PSQI), Epworth Sleepiness Scale (ESS), and clinical/polysomnographic measures in a community sample. J Clin Sleep Med 2008;4:56371. Erişim: https://www.ncbi.nlm.nih.gov/pmc/articles/ PMC2603534/

9. Knutson KL, Rathouz PJ, Yan LL, Liu K, Lauderdale DS. Stability of the Pittsburgh Sleep Quality Index and the Epworth Sleepiness Questionnaires over 1 year in early middle-aged adults: the CARDIA study. Sleep 2006;29:1503-6. [CrossRef] 
10. Saygılı S, Çil Akıncı A, Arıkan H, Dereli E. Üniversite öğrencilerinde uyku kalitesi ve yorgunluk. Ejovoc 2011;1:88-94. Erişim: http://dergipark. ulakbim.gov.tr/ejovoc/article/view/5000085440/5000079527

11. Şenol V, Soyuer F, Pekşen Akça R, Argün M. Adolesanlarda uyku kalitesi ve etkileyen faktörler. Kocatepe Tıp Derg 2012;14:93-102. Erişim: https://kocatepetipdergisi.aku.edu.tr/PDF/MAYIS\%202012/5. pdf

12. Fagerstrom KO. Measuring degree of physical dependence to tobacco smoking with reference to individualization of treatment. Addict Behav 1978;3:235-41. [CrossRef]

13. Uysal MA, Kadakal F, Karşıdağ Ç, Bayram NG, Uysal Ö, Yılmaz V. Fagerström test for nicotine dependence: Reability in a Turkish sample and factor analysis. Tuberk Toraks 2004;52:115-21.

14. Beck AT. An Inventory for measuring depression. Arch Gen Psychiatry 1961;4:561-71. [CrossRef]

15. Hisli N. Beck Depresyon Envanterinin üniversite öğrencileri için geçerliliği, güvenirliği. Turk J Psycho 1989;7:3-13.

16. Beck AT, Epstein N, Brown G, Steer RA. An inventory for measuring clinical anxiety: Psychometric properties. J Consult Clin Psychol 1988;56:893-7. [CrossRef]

17. Ulusoy M, Şahin N, Erkmen $H$. Turkish version of The Beck Anxiety Inventory: psychometric Properties. J Cogn Psychother 1998;12:28-35.

18. Hamilton M. The assessment of anxiety states by rating. Br J Med Psychol 1959;32:50-5. [CrossRef]

19. Yazıcı K, Demir B, Tanrıverdi N, Karaağaoğlu E, Yolaç P. Hamilton anksiyete değerlendirme ölçeği, değerlendiriciler arası güvenirlik ve geçerlik çalışması. Türk Psikiyatri Derg 1998;9:114-7.

20. Johns MW. Reliability and factor analysis of the Epworth Sleepness Scale. Sleep 1992;15:376-81. [CrossRef]
21. İzci B, Ardıç S, Fırat H, Sahin A, Altinors M, Karacan I. Reliability and validity studies of the Turkish version of the Epworth Sleepiness Scale. Sleep Breath 2008;12:161-8. [CrossRef]

22. Buysse DJ, Reynolds CF, Monk TH, Berman SR, Kupfer DJ. The Pittsburgh Sleep Quality Index: a new instrument for psychiatric practice and research. Psychiatry Res 1989;28:193-213. [CrossRef]

23. Ağargün MY, Kara H, Anlar Ö. Pittsburgh uyku kalitesi indeksi'nin geçerliği ve güvenirliği. Türk Psikiyatri Derg 1996;7:107-15.

24. Kutlu R, Çivi S, Karaoğlu O. Polislerde sigara içme sıklığı ve depresyon arasındaki ilişki. Kor Hek 2008;7:31-8. Erişim: https://www. ejmanager.com/mnstemps/1/khb_007_01-31.pdf?t=1566560991

25. Karatay G, Gürarslan Baş N, Aldemir H, Akay M, Bayır M, Onaylı H. Hemşirelik bölümü öğrencilerinin uyku alışkanları ve etkileyen etmenlerin incelenmesi. HSP 2016;3:16-22. [CrossRef]

26. Sayan I, Tekbaş ÖF, Göçgeldi E, Paslı E, Babayiğit M. Bir eğitim hastanesinde görev yapan hemşirelerin sigara içme profilinin belirlenmesi. Genel Tıp Derg 2009;19:9-15. Erişim: http://www. geneltip.org/upload/sayi/59/GTD-00467.pdf

27. Altıntaş $H$, Sevencan $F$, Aslan $T$, Cinel $M$, Çelik E, Onurdağ F. HÜTF dönem dört öğrencilerinin uyku bozukluklarının ve uykululuk hallerinin Epworth Uykululuk Ölçeği ile değerlendirilmesi. Sted 2006;15:114-20. Erişim: http://www.ttb.org.tr/STED/2006/temmuz/ hutf.pdf

28. Üstün $Y$, Çınar Yücel Ş. Hemşirelerin uyku kalitesinin incelenmesi. Maltepe Üniv Hem Bilim Sanat Derg 2011;4:29-38. Erişim: http:// hemsirelik.maltepe.edu.tr/dergiler/nisan/29-38.pdf

29. Asghari A, Kamrava SK, Hemami MR, Jalessi M, Yazdanifard P, Farhadi $M$, et al. Cigarette smoking habit and subjective quality of sleep. Scimetr 2015;3:e18454.

30. Cole JC, Motivala SJ, Buysse DJ, Oxman MN, Levin MJ, Irwin MR. Validation of a 3-factor scoring model for the Pittsburgh Sleep Quality Index in older adults. Sleep 2006;29:112-6. [CrossRef] 